\title{
Subtitusi sebagian jagung dengan kulit kopi olahan sederhana terhadap retensi nitrogen, energi metabolis dan kecernaan bahan kering ransum ayam pedaging
}

\author{
Fajrin Mohamad, Y.L.R. Tulung*, Z. Poli, P.R.R.I. Montong \\ Fakultas Peternakan Universitas Sam Ratulangi Manado, 95115 \\ *Korespondensi (corresponding author): tulungyohannis@gmail.com
}

\begin{abstract}
ABSTRAK
Penelitian ini dilakukan untuk mempelajari kulit kopi olahan sederhana sebagai pengganti jagung dengan level yang berbeda terhadap kecernaan bahan kering, retensi nitrogen, dan energi metabolis semu terkoreksi nitrogen. Penelitian dilakukan dengan menggunakan 24 ekor ayam pedaging unsexed, strain CP707 fase finisher. Rancangan yang digunakan adalah Rancangan Acak Lengkap (RAL) dengan Pola Faktorial 3x4 dengan 2 ulangan. Faktor A merupakan pengolahan kulit kopi dimana A1 yaitu kulit kopi yang dijemur, A2 kulit kopi yang direndam dan A3 kulit kopi yang direbus, sedangkan faktor B yaitu level substitusi B1=0\%, $\mathrm{B} 2=25 \%, \mathrm{~B} 3=50 \%$ dan B4=75\%. Uji lanjut yang digunakan adalah Beda Nyata Jujur (BNJ). Berdasarkan hasil analisis keragaman menunjukkan bahwa interaksi kulit kopi (A) jemur, rendam, rebus dan level substitusi (B) yang berbeda menunjukan hasil yang berbeda nyata $(\mathrm{P}<0,05)$ terhadap nilai retensi nitrogen dan tidak berbeda nyata $(\mathrm{P}>0,05)$ terhadap nilai kecernaan bahan kering. Pada variabel energi metabolis, hasil yang berbeda ditunjukan oleh level substitusi (B) dimana hasil analisis keragaman menunjukan pengaruh yang berbeda sangat nyata $(\mathrm{P}<0,01)$. Persentase nilai kecernaan dalam penelitian ini yaitu nilai retensi nitrogen 28,55\% - 60,88\%, energi metabolis $1351,65 \mathrm{Kkal} / \mathrm{kg}$ - 2561,23 Kkal $/ \mathrm{kg}$, dan kecernaan bahan kering 45,84\% - 63,69\%. Berdasarkan hasil penelitian dapat disimpulkan bahwa penggunaan kulit kopi rendam $25 \%$ memberikan pengaruh terbaik terhadap retensi nitrogen. Penggunaan kulit kopi jemur 50\% memberikan pengaruh terbaik terhadap kecernaan bahan kering, dan penggunaan kulit kopi $25 \%$ memberikan pengaruh terbaik terhadap nilai energi metabolis.
\end{abstract}

Kata kunci: Ayam pedaging, nilai kecernaan, kulit kopi

\begin{abstract}
SUBTITUTION OF PARTICULAR CORN WITH SIMPLE PROCESSED COFFEE LEATHER AGAINST NITROGEN RETENTION, METABOLIC ENERGY, AND DRY INGREDIENTS OF RICE CHICKEN. This research was conducted to study simply processed coffee husks as a substitute for corn with different levels of dry matter digestibility, nitrogen retention, and nitrogen-corrected pseudo-metabolic energy. The study was conducted using 24 unsexed broilers, the finisher phase of the CP707 strain. The design used was a completely randomized design with a $3 \times 4$ factorial pattern with 2 replications. Factor $A$ is the processing of coffee husks where A1 is the dried coffee skin, A2 is soaked coffee skin and A3 boiled coffee skin, while factor B is the substitution level B1 $=0 \%, \mathrm{~B} 2=25 \%, \mathrm{~B} 3=50 \%$ and B4 $=75 \%$. The follow-up test used was Honest Real Difference. Based on the results of the analysis of diversity showed that the interaction of coffee skin (A) drying, soaking, boiling and the substitution level (B) showed significantly different results $(\mathrm{P}<0.05)$ on the nitrogen retention value and was not significantly different $(\mathrm{P}>0,05)$ to the dry matter digestibility
\end{abstract}


value. In the metabolic energy variable, different results were shown by the level of substitution (B) where the results of the analysis of diversity showed a very significant difference $(\mathrm{P}<0.01)$. The percentage of digestibility values in this study were nitrogen retention values $28.55 \%$ $60.88 \%$, metabolic energy $1351.65 \mathrm{Kcal} / \mathrm{kg}-2561.23 \mathrm{Kcal} / \mathrm{kg}$, and dry matter digestibility $45.84 \%-63.69 \%$. Based on this research, it can be concluded that the use of coffee skin soaked $25 \%$ gives the best effect on nitrogen retention. The use of dry coffee skin $50 \%$ gave the best effect on the digestibility of dry matter and the use of $25 \%$ coffee skin gave the best effect on the value of metabolic energy.

Keywords : Broiler chicken, digestibility value, coffee skin

\section{PENDAHULUAN}

Ayam pedaging merupakan salah satu sumber protein hewani yang murah, dibanding dengan ternak yang lain. Keunggulan ayam pedaging adalah pertumbuhannya yang sangat cepat, sehingga dapat dijual sebelum usia 5 minggu, dengan bobot rata-rata $1,5 \mathrm{~kg}$ (Rasyaf, 2006). Pakan merupakan faktor yang sangat berpengaruh dalam menentukan keberhasilan pemeliharaan ayam, khususnya ayam pedaging. Biaya pakan mencapai $60-80 \%$ dari total biaya produksi dan meningkatkan efisiensi protein.

Umumnya peternak ayam pedaging menggunakan ransum komersial untuk memenuhi kebutuhan pakan ternaknya, karena ransum komersial telah disusun sedemikian rupa sehingga memenuhi standard kebutuhan zat makanan yang telah ditetapkan, dan ransum tersebut banyak tersedia di pasaran. Harga ransum komersial relatif mahal sehingga dapat mengurangi keuntungan yang diperoleh peternak, bahkan pada keadaan tertentu dapat menyebabkan kerugian karena biaya produksi jauh lebih besar dari penerimaan penjualan ayam. Hal inilah yang menyebabkan banyak usaha peternakan tidak mampu bertahan.

Salah satu usaha untuk menekan biaya pakan adalah dengan mengurangi penggunakan ransum komersial dan menggantikannya dengan bahan lain yang lebih murah tetapi kebutuhan zat makanan dalam ransum dapat terpenuhi tanpa menyebabkan gangguan terhadap pertumbuhan. Penggunaan bahan pakan lokal menjadi alternatif untuk menekan biaya produksi. Bahan pakan lokal yang digunakan tentunya harus memiliki beberapa fungsi pakan yaitu memiliki kandungan gizi yang dibutuhkan oleh ternak, murah serta mudah didapat. Kandungan gizi utama yang berperan penting bagi pertumbuhan ayam pedaging adalah protein, energi (karbohidrat dan lemak), vitamin, mineral serta air.

Ransum adalah campuran berbagai macam bahan organik dan anorganik yang diberikan kepada ternak untuk memenuhi kebutuhan zat-zat nutrien yang diperlukan bagi pertumbuhan, perkembangan, dan reproduksi (Herlina et al., 2015).

Penggunaan pakan alternatif atau pakan sumber daya lokal dapat memberikan keuntungan apabila syaratnya terpenuhi seperti: ketersediaan berkelanjutan dan memenuhi kebutuhan zat-zat nutrien ternak.

Kulit kopi cukup potensial untuk digunakan sebagai bahan pakan ternak. Kulit kopi mengandung selulosa, hemiselulosa, dan lignin. Lignin merupakan salah satu komponen penyusun tanaman yang membentuk bagian struktural dan sel tumbuhan, yang kandungannya dalam kulit kopi yaitu 52,59\% (Khalil, 2016).

Kandungan lignin yang tinggi dalam limbah kulit kopi dapat menghambat proses pencernaan bagi hewan ternak. Oleh sebab itu sebelum menggunakan bahan pakan lokal maka perlu adanya perlakuan misalnya di panaskan ataupun difermentasi. Bahan pakan yang mengandung anti nutrisi dan berserat kasar tinggi, pada umumnya perlu dilakukan 
pengolahan fisik untuk meningkatkan kandungan zat nutrisi, sehingga daya cerna meningkat dan penggunaan pakan lebih efisien (Khalil, 2016).

Parakkasi (1990) menjelaskan bahwa sistem pencernaan adalah sistem yang terdiri dari saluran pencernaan dan organorgan pelengkap yang berperan dalam proses perombakan bahan makanan, baik secara fisik maupun kimia menjadi zat-zat nutrien yang siap diserap oleh dinding saluran pencernaan.

Kecernaan suatu bahan menurut McDonald et al. (2010) adalah bagian yang terserap dalam saluran pencernaan dan tidak dieksresikan dalam feses. Titus and Fritz (1971) menyatakan bahwa tidak semua bahan pakan dapat dicerna dengan baik. Kegunaan penentuan kecernaan adalah untuk mendapatkan nilai bahan pakan secara kasar, sebab hanya bahan pakan yang dapat dicerna yang dapat diserap. Selanjutnya dinyatakan McDonald et al. (2010) daya cerna suatu bahan pakan yang rendah akan mengakibatkan banyak energi hilang dalam bentuk ekskreta, sehingga nilai energi metabolis menjadi rendah.

Dari uraian diatas maka dilaksanakan penelitian untuk mengkaji tentang penggunaan limbah kulit kopi hasil teknologi sederhana pengganti sebagian jagung dalam ransum dan pengaruhnya terhadap kecernaan bahan kering, retensi nitrogen dan energi metabolis ayam pedaging.

\section{MATERI DAN METODE PENELITIAN}

Penelitian ini telah dilaksanakan di Laboratorium Basah Fakultas Peternakan Universitas Sam Ratulangi Manado. Waktu penelitian dilaksanakan pada saat ayam pedaging fase finisher berumur 7 minggu. Data diambil pada akhir penelitian dengan 5 hari periode penyesuaian (preliminary collecting) dan 3 hari sebagai periode pengambilan data. Penelitian ini menggunakan 24 ekor ayam pedaging unsexed, strain CP 707 fase finisher.

Penelitian ini menggunakan rancangan acak lengkap (RAL) (Steel dan Torrie, 1980) pola faktorial 3x4 dengan 2 ulangan. Faktor A merupakan pengolahan kulit kopi dimana A1 yaitu kulit kopi yang dijemur, A2 kulit kopi yang direndam dan A3 kulit kopi yang direbus, sedangkan faktor B yaitu level substitusi B1=0\%, $\mathrm{B} 2=25 \%, \mathrm{~B} 3=50 \%$ dan B4=75\%. Data yang didapat dianalisis dengan analisis keragaman (Anova) dan apabila berpengaruh nyata maka dilakukan uji lanjut beda nyata jujur (BNJ). Kandang yang digunakan dalam penelitian ini yaitu kandang sistem battery yang berjumlah 24 unit dengan ukuran kandang 15x30x30 cm.

Tempat pakan dibuat dari botol plastik sedangkan tempat minum menggunakan bambu yang telah dibelah. Penempatan kandang diletakan secara sejajar. Perlengkapan lain yang digunakan adalah timbangan "Digital Ohaus" (untuk menimbang ayam, ransum dan ekskreta), wadah penampung ekskreta, tabung penyemprot, alumunium foil, pengaduk dan oven untuk mengeringkan ekskreta. Bahan kimia yang digunakan selama percobaan ini yaitu asam sulfat 5\%, yang berfungsi untuk mencegah hilangnya $\mathrm{N}$ pada ekskreta. Pakan yang digunakan terdiri dari jagung, dedak, konsentrat dan kulit kopi yang telah diolah melalui pengolahan sederhana.

Variabel yang diukur yaitu energi metabolis dan retensi nitrogen menurut petunjuk Zarei (2006) dengan menggunakan rumus :

\section{Kecernaan Bahan Kering (KcBK)}

$\operatorname{KcBK}(\%)=$

$\frac{\text { Konsumsi BK }(\mathrm{g}) \text { - BK ekskreta }(\mathrm{g})}{\text { Konsumsi BK }} \times 100 \%$

Retensi Nitrogen (RN)

$\mathrm{RN}(\%)=\frac{(\mathrm{Fi} \times \mathrm{Nf})-(\mathrm{E} \times \mathrm{Ne})}{(\mathrm{Fi} \times \mathrm{Nf})} \times 100 \%$

Ket :

RN : Retensi Nitrogen (\%) 
Tabel 1. Komposisi zat nutrien bahan makanan penyusun ransum

\begin{tabular}{lcccccc}
\hline Bahan pakan & $\begin{array}{c}\text { Protein } \\
(\%)\end{array}$ & $\begin{array}{c}\text { EM } \\
(\mathrm{kkal})\end{array}$ & $\begin{array}{c}\text { SK } \\
(\%)\end{array}$ & $\begin{array}{c}\text { Lemak } \\
(\%)\end{array}$ & $\begin{array}{c}\text { Ca } \\
(\%)\end{array}$ & $\begin{array}{c}\text { P } \\
(\%)\end{array}$ \\
\hline Jagung *** & 8,42 & 3182 & 2,15 & 5,17 & 0,22 & 0,6 \\
Dedak*** & 12,9 & 2875 & 11,4 & 0,7 & 0,07 & 1,5 \\
Konsentrat** & 38 & 2900 & 6 & 4 & 3 & 1,4 \\
Kulit kopi jemur* & 7,95 & 2895 & 33,6 & 1,3 & 0,21 & 1,08 \\
Kulit kopi rendam* & 10,55 & 2929 & 32,50 & 0,97 & 0,17 & 2,05 \\
Kulit kopi rebus* & 12,23 & 2764 & 20,60 & 1,28 & 0,26 & 0,88 \\
\hline
\end{tabular}

Ket : *) Hasil Analisa Lab ilmu dan teknologi pakan IPB (2016)

**) Hasil Analisa PT. Cargil Indonesia

***) Hasil Analisa Timbulus et al (2017)

Tabel 2. Susunan ransum perlakuan

\begin{tabular}{lcccc}
\hline Bahan Pakan & B0 & B1 & B2 & B3 \\
\hline Konsentrat & 30 & 30 & 30 & 30 \\
Jagung & 40 & 30 & 20 & 10 \\
Dedak & 29 & 29 & 29 & 29 \\
Kulit kopi (A1/A2/A3) & 0 & 10 & 20 & 30 \\
Mineral & 1 & 1 & 1 & 1 \\
Total & 100 & 100 & 100 & 100 \\
\hline
\end{tabular}

Tabel 3. Komposisi zat-zat nutrien ransum perlakuan

\begin{tabular}{|c|c|c|c|c|c|c|c|}
\hline \multirow[b]{2}{*}{ Faktor A } & \multirow[b]{2}{*}{$\begin{array}{c}\text { Faktor } \\
\text { B }\end{array}$} & \multicolumn{6}{|c|}{ Zat-zat Nutrisi } \\
\hline & & $\begin{array}{c}\text { Protein } \\
(\%)\end{array}$ & $\begin{array}{c}\text { EM } \\
(\mathrm{kkal})\end{array}$ & $\begin{array}{c}\text { Serat Kasar } \\
(\%)\end{array}$ & $\begin{array}{c}\text { Lemak } \\
(\%)\end{array}$ & $\begin{array}{c}\text { Kalsium } \\
(\%)\end{array}$ & $\begin{array}{c}\text { Fosfor } \\
(\%)\end{array}$ \\
\hline \multirow{4}{*}{ A1 } & B0 & 18,50 & 2976,55 & 5,96 & 3,47 & 1,0083 & 1,095 \\
\hline & B1 & 18,46 & 2947,85 & 9,11 & 3,08 & 0,1973 & 1,143 \\
\hline & B2 & 18,41 & 2919,15 & 12,25 & 2,69 & 1,0063 & 1,191 \\
\hline & B3 & 18,36 & 2890,45 & 15,40 & 2,31 & 1,0053 & 1,239 \\
\hline \multirow{5}{*}{ A2 } & B0 & 18,50 & 2976,55 & 5,96 & 3,47 & 1,0083 & 1,095 \\
\hline & B1 & 18,72 & 2951,25 & 9,00 & 3,05 & 1,0033 & 1,240 \\
\hline & B2 & 18,93 & 2925,95 & 12,03 & 3,14 & 0,9983 & 1,385 \\
\hline & B3 & 19,14 & 2900,65 & 15,07 & 2,21 & 0,9933 & 1,124 \\
\hline & B0 & 18,50 & 2976,55 & 5,96 & 3,47 & 1,0083 & 1,095 \\
\hline \multirow{3}{*}{ A3 } & B1 & 18,89 & 2934,75 & 8,02 & 3,59 & 1,0123 & 1,123 \\
\hline & B2 & 19,27 & 2892,95 & 9,65 & 2,69 & 2,3063 & 1,15 \\
\hline & B3 & 19,65 & 2851,15 & 11,50 & 2,00 & 1,0203 & 1,179 \\
\hline
\end{tabular}

Keterangan:

Faktor A terdiri dari:

A1 $=$ Kulit kopi jemur

A2 $=$ Kulit Kopi rendam

A3= Kulit kopi rebus

Faktor B Terdiri dari:

B0 $=$ Subtitusi 0\% kulit kopi terhadap jagung

B1 $=$ Subtitusi $25 \%$ kulit kopi terhadap jagung

B2= Subtitusi 50\% kulit kopi terhadap jagung

B3= Subtitusi $75 \%$ kulit kopi terhadap jagung 


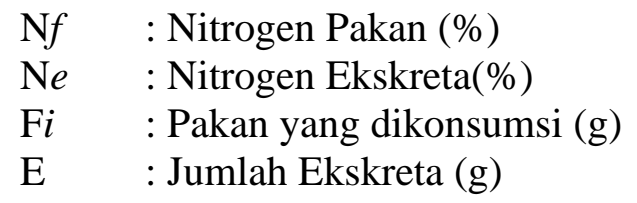

Energi Metabolis (AMEn)

$\operatorname{AMEn}(\%)=\frac{(\mathrm{Fi} \times \mathrm{GEf})-(\mathrm{E} \times \mathrm{GEe})-(\mathrm{NR} \times \mathrm{K})}{(\mathrm{Fi})}$

Ket :

AMEn : Energi metabolis semu yang dikoreksi dengan retensi nitrogen $(\mathrm{Kkal} / \mathrm{kg})$

$\mathrm{Fi} \quad$ : Banyaknya pakan yang dikonsumsi (g)

E : Jumlah Ekskreta $(\mathrm{g})$

GEf : Energi Bruto pakan (Kkal/kg)

GEe : Energi Bruto ekskreta (Kkal/kg)

RN : Retensi Nitrogen

$\mathrm{K}$ : Konstanta koreksi untuk nilai energi nitrogen yang diretensi $(8.73 \mathrm{Kkal} / \mathrm{kg})$ untuk setiap gram nitrogen.

\section{HASIL DAN PEMBAHASAN}

Data hasil penelitian untuk rataan kecernaan bahan kering, retensi nitrogen dan energi metabolis ransum ayam pedaging stain $\mathrm{CP} 707$ selama penelitian disajikan pada Tabel 4.

\section{Pengaruh perlakuan terhadap nilai kecernaan bahan kering}

Kecernaan bahan kering ( $\mathrm{KcBK})$ diukur untuk mengetahui jumlah zat makanan yang diserap tubuh melalui analisis dari jumlah bahan kering, baik dalam ransum maupun dalam feses. Selisih jumlah bahan kering yang dikonsumsi dan jumlah yang diekskresikan adalah kecernaan bahan kering (Boangmanalu, 2016). Nilai KcBK ransum yang menggunakan kulit kopi dalam penelitian ini dapat dilihat pada Tabel 4. Rataan kecernaan bahan kering ransum ayam pedaging yang menggunakan limbah kulit kopi (coffea sp.) berkisar antara 45,84\% $63,69 \%$. Berdasarkan hasil analisis keragaman menunjukkan bahwa interaksi kulit kopi (A) jemur, rendam, rebus dan level substitusi (B) yang berbeda menunjukan hasil yang berbeda tidak nyata $(\mathrm{P}>0,05)$ terhadap nilai $\mathrm{KcBK}$.

Dari data diatas terdapat nilai $\mathrm{KcBK}$ terendah dengan nilai $45,84 \%$, hal ini diduga karena pengaruh laju perjalanan pakan melalui alat pencernaan. Pernyataan ini didukung oleh Anggorodi (1994) yang menyatakan bahwa tinggi rendahnya kecernaan pakan dipengaruhi oleh suhu lingkungan, laju perjalanan pakan melalui alat pencernaan, bentuk fisik bahan pakan, komposisi ransum, dan pengaruh terhadap perbandingan dari zat makanan lain.

Tillman et al. (1998) mengemukakan bahwa bahan kering yang diekskresikan dalam ekskreta merupakan zat-zat nutrien yang tidak diserap tubuh. Dari penelitian ini hasil terbaik didapat oleh penggunan kulit kopi jemur (A1) dengan level substitusi $50 \%$ (B2) dengan nilai 63,69\% sehingga dapat direkomendasikan. Hal ini sejalan dengan pernyataan Blair et al. (1990) yang disitasi oleh Rambet et al. (2016) bahwa $\mathrm{KcBK}$ ransum ayam pedaging fase finisher berkisar pada angka 50-80\%.

\section{Pengaruh perlakuan terhadap nilai retensi nitrogen}

Retensi nitrogen (RN) merupakan salah satu metode untuk menilai kualitas protein ransum dengan mengukur konsumsi nitrogen dan pengeluaran nitrogen dalam ekskreta dan urin (The et al., 2017). Nilai Retensi Nitrogen diperoleh dari selisih antara jumlah nitrogen yang dikonsumsi dikurangi jumlah nitrogen dalam pakan. Perhitungan retensi protein dapat diduga dari retensi nitrogen suatu bahan pakan dan untuk mengkonversi protein menjadi nitrogen hendaknya dibagi dengan angka 6,25 (Situmorang, 2013). Nilai RN ransum yang menggunakan kulit kopi dalam penelitian ini dapat dilihat pada Tabel 4 . Hasil analisis keragaman menunjukkan bahwa interaksi kulit kopi (A) jemur, 
Tabel 4. Rataan Kecernaan Bahan Kering, Retensi Nitrogen dan Energi Metabolis Ransum Ayam Pedaging Stain CP 707 Selama Penelitian

\begin{tabular}{|c|c|c|c|c|c|}
\hline \multirow{2}{*}{ Variabel } & \multirow{2}{*}{$\begin{array}{l}\text { Level } \\
\text { subtitusi }\end{array}$} & \multicolumn{3}{|c|}{ Perlakuan } & \multirow[b]{2}{*}{ Rataan } \\
\hline & & $\mathrm{A} 1$ & $\mathrm{~A} 2$ & A3 & \\
\hline \multirow{5}{*}{$\begin{array}{l}\text { Kecernaan } \\
\text { Bahan } \\
\text { Kering } \\
\quad(\%)\end{array}$} & B0 & $59,59 \pm 3,71$ & $58,94 \pm 0,93$ & $59,26 \pm 2,32$ & $59,26 \pm 1,39$ \\
\hline & B1 & $56,84 \pm 7,64$ & $57,76 \pm 0,71$ & $57,04 \pm 13,80$ & $57,21 \pm 6,55$ \\
\hline & $\mathrm{B} 2$ & $63,69 \pm 4,84$ & $52,00 \pm 9,19$ & $45,84 \pm 1,80$ & $53,84 \pm 3,71$ \\
\hline & B3 & $62,16 \pm 0,20$ & $50,17 \pm 4,63$ & $52,72 \pm 9,31$ & $55,02 \pm 4,56$ \\
\hline & Rataan & $60,56 \pm 3,08$ & $54,72 \pm 3,98$ & $53,72 \pm 5,78$ & \\
\hline \multirow{5}{*}{$\begin{array}{l}\text { Retensi } \\
\text { Nitrogen } \\
\qquad(\%)\end{array}$} & B0 & $60,25 \pm 3,55$ & $60,88 \pm 0,88$ & $60,57 \pm 2,21$ & $60,57 \pm 1,34$ \\
\hline & B1 & $52,97 \pm 8,68^{\mathrm{a}}$ & $58,74 \pm 2,43^{b}$ & $46,81 \pm 3,31^{\mathrm{c}}$ & $52,84 \pm 3,38$ \\
\hline & B2 & $53,50 \pm 0,47^{\mathrm{a}}$ & $37,66 \pm 2,85^{\mathrm{b}}$ & $37,54 \pm 5,77^{\mathrm{b}}$ & $42,90 \pm 2,65$ \\
\hline & B3 & $37,43 \pm 2,66^{\mathrm{a}}$ & $28,55 \pm 2,13^{\mathrm{b}}$ & $30,31 \pm 1,39^{c}$ & $32,10 \pm 0,64$ \\
\hline & Rataan & $51,04 \pm 3,48$ & $46,46 \pm 0,85$ & $43,81 \pm 1,90$ & \\
\hline \multirow{5}{*}{$\begin{array}{l}\text { Energi } \\
\text { Metabolis } \\
(\mathrm{Kkal} / \mathrm{kg})\end{array}$} & B0 & $2535,83 \pm 143,71$ & $2561,23 \pm 35,93$ & $2548,52 \pm 89,82$ & $2548,53 \pm 53,89^{a}$ \\
\hline & B1 & $2477,10 \pm 297,84$ & $2448,16 \pm 99,73$ & $2345,82 \pm 108,80$ & $2423,69 \pm 111,85^{b}$ \\
\hline & B2 & $2209,94 \pm 20,64$ & $1839,01 \pm 101,22$ & $2110,57 \pm 186,72$ & $2053,17 \pm 83,05^{\mathrm{c}}$ \\
\hline & B3 & $1351,65 \pm 116,69$ & $1582,61 \pm 74,22$ & $1569,68 \pm 49,33$ & $1501,31 \pm 34,06^{\mathrm{d}}$ \\
\hline & Rataan & $2143,63 \pm 114,93$ & $2107,75 \pm 30,53$ & $2143,65 \pm 57,64$ & \\
\hline
\end{tabular}

Keterangan : Superskrip berbeda menunjukkan perbedaan yang nyata $(\mathrm{P}<0,05)(\mathrm{abc})$ dan sangat nyata $(\mathrm{P}<0,01)(\mathrm{ABCD})$.

rendam, rebus dan level substitusi (B) yang satuan nyata $(\mathrm{P}<0,05)$ terhadap nilai $\mathrm{RN}$. Uji lanjut BNJ RN pada faktor interaksi menunjukan hasil yang berbeda nyata $(\mathrm{P}<0,05)$. Pada ransum kombinasi perlakuan tidak ditemukan hasil yang berbeda nyata antara A1B0 $(60,25), \mathrm{A} 2 \mathrm{~B} 0$ $(60,88)$ dan A3B0 $(60,57)$. Perbedaan didapatkan pada kombinasi perlakuan A1B1 (52,97) dibandingkan dengan perlakuan kombinasi A2B1 $(58,74)$ dan A3B1 $(46,81)$ dimana hasil uji menunjukan perbedaan yang nyata $(\mathrm{P}<0,05)$. Perlakuan kombinasi A1B2 $(53,50)$ berbeda nyata dengan A2B2 $(37,66)$ dan A3B2 $(37,54)$ sedangkan A2B2 dan A3B2 tidak memberikan perbedaan yang nyata. Perlakuan kombinasi A1B3 $(37,43)$, A2B3 $(28,55)$ dan A3B3 $(30,31)$ memberikan perbedaan yang nyata $(\mathrm{P}>0,05)$. Rataan penelitian ini berkisar antara 28,55\% $60,88 \%$, nilai ini berada di bawah efisiensi protein yang diretensi oleh ayam pedaging dari protein ransum yang dikonsumsi sebesar 67\% (Wahju, 2004).

Penurunan nilai RN disebabkan meningkatnya protein ransum dikarenakan sebagian protein digunakan untuk memenuhi kebutuhan energi. Faktor lain yang mempengaruhi niai $\mathrm{RN}$ adalah konsumsi ransum, konsumsi protein, kualitas protein, daya cerna serat kasar, imbangan zat-zat nutrisi dalam ransum dan kondisi ternak (Dianti et al., 2012). Dalam penelitian ini, jumlah protein yang rendah dalam ransum serta serat kasar yang tinggi menyebabkan laju digesta semakin cepat, sehingga dengan nyata menurunkan nilai RN ayam pedaging namun tetap menunjukkan respon yang positif. Nilai $\mathrm{RN}$ positif berarti bahwa jumlah nitrogen yang mampu dikonsumsi oleh ayam pedaging lebih besar dari jumlah nitrogen yang keluar melalui ekskreta.

Penelitian ini membuktikan bahwa ransum yang menggunakan kulit kopi sampai pada level 75\% (B3) menunjukan respon yang positif pada ayam pedaging terhadap nilai $\mathrm{RN}$, walau dengan menggunakan ransum yang berserat kasar tinggi. Tetapi untuk penelitian berikutnya disarankan untuk mengganti metode pengolahannya dengan metode yang lain seperti metode pengolahan fermentasi agar kandungan faktor pembatas menurun dan kandungan nutrienya meningkat, supaya dapat menaikan nilai $\mathrm{RN}$. 


\section{Pengaruh perlakuan terhadap energi metabolis}

Energi metabolis merupakan energi makanan dikurangi energi yang hilang dalam ekskreta, pembakaran gas-gas dan urin (Mario et al., 2013). Nilai energi metabolis dalam penelitian ini adalah nilai energi metabolis semu terkoreksi nitrogen (AMEn). Nilai AMEn ransum yang menggunakan kulit kopi dalam penelitian ini dapat dilihat pada tabel 4. Hasil analisis keragaman menunjukkan bahwa interaksi kulit kopi (A) jemur, rendam, rebus dan level substitusi (B) tidak memberikan pengaruh yang berbeda $(\mathrm{P}>0,05)$ terhadap nilai AMEn. Sedangkan hasil yang berbeda ditunjukan oleh level substitusi (B) dimana perlakuan kombinasi kulit kopi level $0 \%$, $25 \%, 50 \%$ dan $75 \%$ memberikan hasil yang berbeda sangat nyata $(\mathrm{P}<0,01)$. Dari hasil uji BNJ level substitusi (B), perlakuan level substitusi B0 $(2548,53)$ berbeda sangat nyata dengan B1 $(2423,69)$, B2 $(2053,17)$ dan B3 $(1501,31)(\mathrm{P}<0,01)$. Perlakuan level substitusi $\mathrm{B} 1$ berbeda sangat nyata dengan B2 dan B3 $(\mathrm{P}<0,01)$, dan perlakuan B2 berbeda sangat nyata dengan $\mathrm{B} 3(\mathrm{P}<0,01)$.

Rataan dalam penelitian ini berkisar antara $1351,65 \mathrm{Kkal} / \mathrm{kg}-2561,23 \mathrm{Kkal} / \mathrm{kg}$, nilai ini lebih rendah dibandingkan dengan laporan Siabandi et al. (2018) dimana nilai AMEn yang dihasilkan dengan penggunaan tepung silase kulit pisang kepok (Musa paradisiaca formatypica) yaitu 2557,31 $\mathrm{Kkal} / \mathrm{kg}$ - 3040,05 $\mathrm{Kkal} / \mathrm{kg}$. Hal ini disebabkan oleh kandungan serat kasar yang tinggi dalam ransum ayam pedaging. Sesuai pernyataan Parimartha et al. (2011), bahwa kandungan serat kasar yang tinggi dapat meningkatkan laju digesta sehingga nilai kecernaan zat makanan termasuk energi rendah sebab banyak yang keluar bersama ekskreta.

Pada penelitian ini, kandungan energi metabolis yang rendah didapat mulai penggunaan kulit kopi A2B2 (1839,01 $\mathrm{Kkal} / \mathrm{kg}$ ), diikuti A2B3 (1582,61 Kkal/kg), A3B3 (1569,68 $\mathrm{Kkal} / \mathrm{kg})$ dan A1B3 $(1351,65 \mathrm{Kkal} / \mathrm{kg})$. Dari hasil ini dapat disimpulkan perlakuan kombinasi dengan level substitusi $25 \%$ dapat direkomendasikan karena nilai AMEnnya berkisar antara $2345 \mathrm{Kkal} / \mathrm{kg}$ - 2477 $\mathrm{Kkal} / \mathrm{kg}$, sedangkan untuk perlakuan kombinasi kulit kopi level 50\% dan 75\% bisa digunakan untuk penelitian berikutnya, tetapi dengan menggunakan metode pengolahan yang berbeda seperti metode pengolahan fermentasi agar kualitas nutriennya meningkat dan faktor pembatasnya menurun.

\section{KESIMPULAN}

Berdasarkan penelitian ini dapat disimpulkan bahwa penggunaan kulit kopi rendam 25\% memberikan pengaruh terbaik terhadap retensi nitrogen. Penggunaan kulit kopi jemur $50 \%$ memberikan pengaruh terbaik terhadap kecernaan bahan kering, dan penggunaan kulit kopi 25\% memberikan pengaruh terbaik terhadap nilai energi metabolis.

\section{DAFTAR PUSTAKA}

Anggorodi, R. 1994. Ilmu Makanan Ternak Umum. PT Gramedia Jakarta.

Boangmanalu, R., T. H. Wahyuni dan S. Umar. 2016. Kecernaan Bahan Kering, Bahan Organik dan Protein Kasar Ransum yang Mengandung Tepung Limbah Ikan Gabus Pasir (Butis amboinensis) Sebagai Substitusi Tepung Ikan Pada Broiler. Jurnal Peternakan Integratif 4(3): 329-340.

Dianti, R., Mulyono dan F. Wahyono. 2012. Pemberian daun Clotalaria usaramoensis sebagai sumber protein ransum burung puyuh periode grower terhadap energi metabolis, retensi nitrogen dan efisiensi ransum. Indonesian Journal of Food Technology. Vol. 1(1) : 16-28.

Herlina B., R. Novita dan T. Karyono. 2015. Pengaruh jenis dan waktu pemberian ransum terhadap performans pertumbuhan dan 
produksi ayam broiler. Jurnal Sains Peternakan Indonesia 10(2): 107-113

Khalil, M. 2016. Pengaruh Pemberian limbah kulit kopi (Coffea sp.) amoniasi sebagai pakan alternatif terhadap pertambahan bobot ayam broiler. Jurnal Ilmiah Mahasiswa Pendidikan Biologi 1(1) : 119 - 130.

Mario W., E. Widodo dan O. Sjofjan. 2013. Pengaruh penambahan kombinasi tepung jahe merah, kunyit dan meniran dalam pakan terhadap kecernaan zat makanan dan energi metabolis ayam pedaging. Jurnal Ilmu-Ilmu Peternakan 24 (1):1-8.

McDonald, P., R.A. Edwards, J.F.D. Greenhalgh, C.A. Morgan, L.A. Sinclair dan R.G. Wilkinson. 2010. Animal Nutrition. $7^{\text {th }}$ Ed. Prentice Hall, Pearson, Harlow, England, London, New York, Boston, San Fransisco, Toronto, Sydney, Tokyo, Singapore, Hong Kong, Seoul, Taipei.

Parakkasi, A. 1990. Ilmu Nutrisi dan Makanan Ternak Monogastrik. Angkasa. Bandung.

Rasyaf, M. 2006. Beternak Ayam Pedaging. Penerbit Penebar Swadaya.Jakarta.

Rambet, V., J.F. Umboh, Y.L.R. Tulung dan Y.S. Kowel. 2016. Kecernaan protein dan energi ransum broiler yang menggunakan tepung maggot (Hermetia illucens) sebagai pengganti tepung ikan. Zootec 36(1): $13-22$.

Siabandi, R., B. Bagau., M. R. Imbar dan M. N. Regar. 2018. Retensi nitrogen dan energi metabolis ransum broiler yang mengandung tepung silase kulit pisang kepok (Musa paradisiaca formatypica). Zootec 38(1): 226-234.

Situmorang N. A, L.D. Mahfudz dan U. Atmomarsono. 2013. Pengaruh pemberian tepung rumput laut (Gracilaria verrucosa) dalam ransum terhadap efisiensi penggunaan protein ayam broiler. Journal Animal Agricultur 2(1): 49-56
Steel, R. G. D. dan J. H. Torrie. 1980. Principles and Procedures of Statistics A Biometrical Approach. Second Edition. McGraw-Hill International Book Company. Tokyo. 633.

Parimartha., K.W.S., N.L.G. Sumardani., I.G.N.G. Bidura., I.G.N. Kayana dan S. A. Lindawati. 2011. Penambahan multi enzim dan ragi tape dalam ransum berserat tinggi (pod kakao) untuk menurunkan kolesterol daging broiler. Jurnal Veteriner. Vol. 12 (1) : 69-76.

The, F., J. S. Mandey., Y. H. S. Kowel dan M. N. Regar. 2017. Nilai retensi nitrogen dan energi metabolis broiler yang diberi ransum tepung limbah sawi putih (Brassica rapa L. Subsp. pekinesis). Zootec 37(1): 41-49.

Tillman, A. D., H. Hartadi., S. Reksohadiprodjo., S. P. Kusumo dan S. Lebdosoekojo. 1998. Ilmu Makanan Ternak Dasar. Gajah Mada University Press. Yogyakarta.

Timbulus. C.M., P.R.R.I. Montong, A. Dp. Mirah dan S. E. Siswosubroto. 2017. Penampilan produksi ternak babi grower yang menggunakan tepung kulit kopi sebagai bahan pengganti sebagian dedak halus pada pakan. Zootec 37(2): 242-251.

Titus, H. W., and J. C. Fritz. 1971. The Scientific Feeding of Chickens. $5^{\text {th }}$ Ed. The Interstate Printers \& Publishers, Inc. Danville, Illinois.

Wahju, J. 2004. Ilmu Nutrisi Unggas. Edisi ke-4. Gadjah Mada University Press, Yogyakarta.

Zarei, A. 2006. Apparent and true metabolizable energy in Artemia meal. Int. J. of Poult. Sci. 5(7): 627628 